\title{
Hjelper antidepressiver mot depresjon?
}

\author{
Vi er i økende grad blitt klar over antidepressivenes manglende effekt ved depresjon. Likevel forskrives de \\ stadig hyppigere. Bør jeg som snart nyutdannet lege videreføre denne tradisjonen, eller er det på tide å endre \\ klinisk praksis?
}

Mange studier viser at antidepressiver av typen selektive serotoninreopptakshemmere (SSRI) har effekt mot depresjon. Siden de fleste av disse studiene er helt eller delvis sponset av produsenten er det imidlertid potensial for overestimering av behandlingseffekten (1). Det er også kjent at positive studier publiseres i langt større grad enn negative (2). Jeg mener derfor at det er på høy tid å evaluere bruken av SSRI-preparater på nytt.

I en metaanalyse fra 2008 fant forfatterne at selektive serotoninreopptakshemmere har en liten klinisk, relevant effekt på alvorlig depresjon, men ikke på mild og moderat depresjon (3). Andre har pekt på at effekten av slike medikamenter versus placebo er mindre i nyere studier sammenlignet med eldre (4).

Ifølge det digitale oppslagsverket UpToDate tilskrives «den lille fordelen i favør antidepressiver over placebo blant deprimerte pasienter delvis uspesifikke kliniske effekter av placebobehandling: å motta placebobehandling er ikke det samme som å motta ingen behandling» (min oversettelse) (5).

Selektive serotoninreopptakshemmere er altså knapt bedre enn placebo, mens placebo er klart bedre enn ingen behandling (6). I en ny metaanalyse, som inkluderte 27 422 pasienter, konkluderer man med at selektive serotoninreopptakshemmere ikke har klinisk relevant effekt på alvorlig depresjon (7). Den statistisk signifikante forbedringen i favør av medikamentet i forhold til placebo ble der vurdert til å være for liten til å være klinisk relevant. Statistisk signifikans i form av en p-verdi forteller altså ikke om resultatet er klinisk relevant. Videre ble det i de fleste av disse randomiserte, placebokontrollerte studiene brukt bivirkningsfritt placebo som indirekte kan øke effekten av aktiv behandling (8).

\section{Usikker bivirkningsprofil}

Bivirkninger som seksuell dysfunksjon og apati er vanlige ved bruk av selektive serotoninreopptakshemmere (9), og i mange publiserte studier utelater forskerne registrerte bivirkninger (10). Det er også vanlig at deprimerte pasienter med høy selvmordsfare ekskluderes fra studier, noe som er fornuftig hvis annen effektiv behandling finnes, men ekskluderingen gjør det vanskelig å vurdere hvordan medikamentene påvirker sann- synligheten for selvmord i denne gruppen. Når så forskere, uavhengige av industrien, ikke får full tilgang til data om pasientenes bivirkninger, svekker dette tilliten til medikamentene ytterligere (11).

\section{«I mange publiserte studier utelater forskerne registrerte bivirkninger»}

Minimal effekt og negativ bivirkningsprofil leder til den konklusjon at jeg som lege ikke bør behandle deprimerte pasienter med selektive serotoninreopptakshemmere.

\section{Kunnskapspyramide på hodet}

At mange trekker motsatt konklusjon får meg til å undre om jeg kanskje allikevel tar feil. Noen tror kanskje mer på de tallrike industrisponsede studiene som viser god effekt og lite bivirkninger, enn på de presumptivt færre negative studiene?

Som medisinstudent vet jeg at det er få som reiser rundt til legekontorer og sykehus med påsmurte baguetter for å formidle negative resultater. En annen forklaring kan være at mange anser forskningsresultater som upålitelige og lite relevante for klinisk praksis, og derfor stoler mer på egne erfaringer.

Den eneste logiske, gyldige slutningen jeg kan trekke når en deprimert pasient har fătt forskrevet selektive serotoninreopptakshemmere og er blitt bedre, er at pillene ikke fratok pasienten muligheten til å bli bedre. Mange vil da innvende at kliniske studier sjelden representerer forholdene i den virkelige verden, noe jeg lett slutter meg til. De selekterte utvalgene i studiene representerer imidlertid som oftest de pasientene med minst komorbiditet og best prognose. Så når selektive serotoninreopptakshemmere ikke virker, selv på de friskeste pasientene med depresjon, er det enda mindre grunn til å tro at den virker på andre pasienter.

Morten Svendsen Næss

mna014@post.uit.no
Morten Svendsen Næss (f. 1976) er medisin- og forskerlinjestudent ved Universitetet i Troms $\varnothing$ Norges arktiske universitet. Han er autorisert kiropraktor siden 2005 og har en mastergrad i treningsfysiologi fra Norges teknisk-naturvitenskapelige universitet 2010.

Forfatter har fylt ut ICMJE-skjemaet og oppgir ingen interessekonflikter.

\section{Litteratur}

1. Purgato M, Papola D, Gastaldon C et al. Paroxetine versus other anti-depressive agents for depression. Cochrane Database Syst Rev 2014: nr. 4: CD006531.

2. Turner EH, Matthews AM, Linardatos E et al. Selective publication of antidepressant trials and its influence on apparent efficacy. N Engl J Med 2008; 358: 252-60.

3. Kirsch I, Deacon BJ, Huedo-Medina TB et al. Initial severity and antidepressant benefits: a meta-analysis of data submitted to the Food and Drug Administration. PLoS Med 2008; 5: e45.

4. Khin NA, Chen YF, Yang Y et al. Exploratory analyses of efficacy data from major depressive disorder trials submitted to the US Food and Drug Administration in support of new drug applications. J Clin Psychiatry 2011: 72: 464-72.

5. Jakobsen JC, Katakam KK, Schou A et al. Selective serotonin reuptake inhibitors versus placebo in patients with major depressive disorder. A systematic review with meta-analysis and Trial Sequential Analysis. BMC Psychiatry 2017; 17: 58.

6. Simon G. Unipolar major depression in adults: Choosing initial treatment. UpToDate versjon 23.12.2015. www.uptodate.com/contents/ unipolar-major-depression-in-adults-choosinginitialtreatment (10.3.2017)

7. Kirsch I. Antidepressants and the placebo effect. Z Psychol 2014; 222: 128-34

8. Moncrieff J, Wessely S, Hardy R. Active placebos versus antidepressants for depression. Cochrane Database Syst Rev 2004: nr. 1: CD003012.

9. Hu XH, Bull SA, Hunkeler EM et al. Incidence and duration of side effects and those rated as bother some with selective serotonin reuptake inhibitor treatment for depression: patient report versus physician estimate. J Clin Psychiatry 2004: 65: 959-65.

10. Hughes S, Cohen D, Jaggi R. Differences in repor ting serious adverse events in industry sponsored clinical trial registries and journal articles on antidepressant and antipsychotic drugs: a cross-sectional study. BMJ Open 2014; 4: e005535

11. Hetrick S, Merry S, McKenzie J et al. Selective serotonin reuptake inhibitors (SSRIs) for depressive disorders in children and adolescents. Cochrane Database Syst Rev 2007; nr. 3: CD004851.

Mottatt 21.3. 2017, første revisjon innsendt 28.3. 2017, godkjent 29.3. 2017. Redaktør: Ketil Slagstad.

Publisert først på nett. 